\title{
Knowledge and Perception of Hand Hygiene among House Officers in a Tertiary Health Care Centre in Punjab, Pakistan
}

\author{
Muhammad Faheem Afzal, ${ }^{1}$ Amna Shafiq, ${ }^{2}$ Muhammad Naeem Afzal, ${ }^{3}$ Akmal Laeeq Chishti, ${ }^{4}$ Asif Hanif ${ }^{5}$
}

\section{Abstract}

Background: Hand hygiene is one of the primary measures to reduce healthcare-associated infections (HCAIs). There is a need to explore the concept of hand hygiene among the medical graduates.

Objective: To assess the knowledge and perception of hand hygiene among house officers in a tertiary health care centre.

Patients and Methods: This cross sectional survey was conducted in the departments of Paediatrics, Internal Medicine, Surgery and Obstetrics / Gynaecology, in affiliated hospitals of King Edward Medical University / Mayo Hospital, Lahore from October to December 2015. World Health Organization's validated hand hygiene knowledge and perception questionnaire was used. A total of 100 fresh medical

${ }^{1}$ Assistant Professor of Paediatrics

KEMU / Mayo Hospital, Lahore

${ }^{2}$ House Officer, Paediatrics

King Edward Medical University, Lahore

${ }^{3}$ Assistant Professor of Internal Medicine

KEMU / Mayo Hospital, Lahore.

${ }^{4}$ Dean Faculty of Medicine, Chairman/Professor,

Department of Paediatrics, KEMU / Mayo Hospital,

Lahore

${ }^{5}$ Biostatistician, PGMI / Gulab Devi Hospital, Lahore

Date of Submission 17-02-2016

Date of Revision Received 09-06-2016

Date of Acceptance for Publication 27-07-2016

Conflict of Interest: None

Funding Source: None

\section{Contribution}

All the Authors have contributed in Study Design, Data Collection, Data Analysis, Data Interpretation, Manuscript Writing and Statistical Analysis. graduates, who passed their MBBS in March - April 2015 , working as house officers were included in the study by non-probability convenient sampling. The data were entered in SPSS 20 for statistical analysis. Chi square test was used for comparison.

Results: Of 100 house officers approached, 67 participated in this study. Only 20 (29\%) had received formal training in hand hygiene and $40(59 \%)$ practiced routine use of alcohol hand rub. The study did not document satisfactory level of knowledge regarding hand hygiene. Overall, 27 (40.3\%) house officers had correct knowledge of main route of transmission of potential harmful germs, while 23 (34.3\%) house officers had correct knowledge of main source of germs in HCAI. Only, 41 (61.2\%) house officers correctly knew of 20 seconds as the minimum time required for effective alcohol-based hand rub. The house officers were of the opinion that alcohol - based hand rub must be available at health - care facility at each point of care and awareness posters should be displayed at same points as reminders. Actions taken by leaders and managers regarding effective measures towards hand hygiene were considered effective in improving the hand hygiene practices.

Conclusion: The unsatisfactory level of knowledge regarding hand hygiene indicates that the house officers require increased emphasis on hand hygiene education and improvement in their current primary training as well as undergraduate curricula.

Key words: Knowledge, Perception, Hand hygiene, house officers.

\section{Introduction}

Hand hygiene is one of the primary measures to reduce healthcare associated infections (HCAIs). ${ }^{1}$ The fore- 
most historical evidence on importance of hand hygiene was revealed in a maternity clinic in Vienna in 1847 , where practice of hand hygiene by medics reduced maternal mortality. Further studies indicated that hand hygiene is the measure to reduce the spread of infectious diseases. It has been suggested that the incidence of HCAIs can potentially be reduced largely if hand hygiene is followed as per recommendations. ${ }^{2}$

Authors from different studies have found the poor compliance of hand hygiene among healthcare workers, despite the relative simplicity of hand hygiene procedure. The risk of HCAI can be reduced by creating awareness, providing proper hand hygiene education, and training. ${ }^{3}$ In order to emphasize the importance of hand washing, October 15 has been declared as the Global Hand Washing Day by UNICEF since 2008. ${ }^{4}$ The World Health Organization (WHO) has introduced an evidence-based concept and guidelines on hand hygiene in healthcare so that understanding, training, monitoring, and reporting of hand hygiene may be improved. ${ }^{5}$ This concept and guidelines have been extensively used in the training of professional health workers but is rarely taught in the undergraduate curriculum, leading to poor knowledge, and observance of hand hygiene by the medical graduates. ${ }^{6-8}$

There is a need to explore the concept of hand hygiene among the medical graduates. It is imperative to inculcate the knowledge, and perception regarding hand hygiene at the time of medical education. Therefore, the present study was conducted to assess the knowledge and perception of hand hygiene among fresh graduates working as house officers in a tertiary health care centre.

\section{Patients and Methods}

This cross sectional survey was conducted in the departments of Paediatrics, Internal Medicine, Surgery and Obstetrics / Gynaecology, in hospitals of Mayo Hospital, Lahore from October to December 2015. This study was approved by institutional review board. The study instrument used was the questionnaire for knowledge and perception survey for health care workers, originally developed by the WHO. ${ }^{9,10}$ The questionnaire consisted of two basic questions, eight domains assessing the knowledge and eleven domains assessing the perception of hand hygiene. To determined the content validity of the questionnaire, a panel of experts was requested to comment on whether the questionnaire adequately sampled hand hygiene know- ledge and perception, whether the questions and items in the questionnaire were accurate, clear, and easy to understand, whether the instructions were clear and complete, whether any of the questions or statements were likely to discourage the participant from answering, and whether the response options were adequate for the questions and statements. Face validity was determined through the pilot testing of the questionnaire on four house officers of each specialty. A total of one hundred fresh medical graduates, who passed their MBBS in March - April 2015, working as house officers in the departments of Paediatrics, Internal Medicine, Surgery and Obstetrics/Gynaecology were approached to be included in the study by non-probability convenient sampling. The participants were briefed about study and were requested to fill the questionnaire anonymously. This study excluded the responses where more than three questions were unanswered. The data were entered in SPSS 20 for statistical analysis. Domains were presented as frequency tables. Chi square test was applied to see the differrence between responses from house officers working in different departments. A $p$ value of $<0.05$ was considered to be significant.

\section{Results}

Of 100 house officers approached, 67 participated in this study. Of these, 23 house officers were from Internal Medicine, 13 from General Surgery, 15 from Obstetrics / Gynaecology while 16 were from Paediatrics. Only 20 (29\%) claimed to receive formal training in hand hygiene and $40(59 \%)$ practiced routine use of alcohol hand rub (Table 1).

The participants' hand hygiene knowledge has been summarized in Table 2. Overall, 27(40.3\%) house officers had correct knowledge about main route of transmission of potential harmful germs. The differrence in response to this question was statistically significant where house officers from Medicine considered "Health care workers' hands when not clean" better response (0.004). Only 23(34.3\%) house officers were aware that the main source of germs in HCAI was from patients. Only, 41(61.2\%) house officers correctly knew that 20 seconds is the minimum time required for effective alcohol-based hand rub as per WHO guideline. The study did not document satisfactory level of knowledge regarding the correct type of hand hygiene method for certain situations. As response to the question regarding the need to avoid colo- 
nization, no statistically significant difference of knowledge was observed regarding use of jewelry, damaged skin, artificial nails, and regular use of hand cream (Table 2).

The participants' hand hygiene perception has been summarized in Table 3 . There was no significant difference in the responses except two. As compared to other house officers, Paediatrics house officers considered "The health care facility makes alcohol-based hand rub always available at each point of care"
(0.001) and Obstetrics house officers considered "Hand hygiene posters are displayed at point of care as reminders" very effective (0.001). The house officers were of opinion that hand hygiene is an effective method to reduce the HCAIs. They were also of opinion that the actions taken by leaders and managers regarding effective measures towards hand hygiene will create the difference in improving the hand hygiene practice (Table 3 ).

Table 1: Hand hygiene's Training $\&$ use of hand rub by house officers $(n=67)$. (The figures in parenthesis are percentages).

\begin{tabular}{|c|c|c|c|c|c|c|c|c|}
\hline Variables & & $\begin{array}{l}\text { Medicine } \\
(\mathbf{n}=23)\end{array}$ & $\begin{array}{l}\text { Surgery } \\
(\mathbf{n}=13)\end{array}$ & $\begin{array}{l}\text { Obstetric } \\
\mathrm{s}(\mathrm{n}=15)\end{array}$ & $\begin{array}{l}\text { Paediatric } \\
\mathrm{s}(\mathrm{n}=16)\end{array}$ & $\begin{array}{c}\text { Total } \\
(\mathbf{n}=67)\end{array}$ & $\begin{array}{c}\text { Chi Square } \\
\text { (df) }\end{array}$ & P-value \\
\hline \multirow{2}{*}{$\begin{array}{l}\text { Formal training in } \\
\text { hand hygiene }\end{array}$} & Yes & $5(21.7)$ & $3(23.1)$ & $6(40.0)$ & $6(37.5)$ & $20(29.9)$ & \multirow{2}{*}{$2.19(3)$} & \multirow{2}{*}{0.533} \\
\hline & No & $18(78.3)$ & $10(76.9)$ & $9(60.0)$ & $10(62.5)$ & $47(70.1)$ & & \\
\hline \multirow{2}{*}{$\begin{array}{l}\text { Use of alcohol } \\
\text { based hand rubs }\end{array}$} & Yes & 17 (73.9) & $5(38.5)$ & 7 (46.7) & $11(68.8)$ & $40(59.7)$ & \multirow{2}{*}{$5.97(3)$} & \multirow{2}{*}{0.113} \\
\hline & No & $6(26.1)$ & $8(61.5)$ & $8(53.3)$ & $5(31.2)$ & $27(40.3)$ & & \\
\hline
\end{tabular}

Table 2: Hand hygiene's Knowledge of House Officers $(n=67)$. (The figures in parenthesis are percentages).

\begin{tabular}{|l|c|c|c|c|c|c|c|}
\hline \multicolumn{1}{|c|}{ Variables } & $\begin{array}{c}\text { Medicine } \\
(\mathbf{n}=\mathbf{2 3})\end{array}$ & $\begin{array}{c}\text { Surgery } \\
(\mathbf{n}=\mathbf{1 3})\end{array}$ & $\begin{array}{c}\text { Obstetrics } \\
(\mathbf{n}=15)\end{array}$ & $\begin{array}{c}\text { Paediatrics } \\
(\mathbf{n}=16)\end{array}$ & $\begin{array}{c}\text { Total } \\
(\mathbf{n}=\mathbf{6 7})\end{array}$ & $\begin{array}{c}\text { Chi square } \\
(\mathbf{d f})\end{array}$ & $\begin{array}{c}\text { P- } \\
\text { value }\end{array}$ \\
\hline $\begin{array}{l}\text { Main route of cross transmission } \\
\text { of germs }\end{array}$ & $14(60.9)$ & $1(7.7)$ & $6(40)$ & $6(37.5)$ & $27(40.3)$ & $24.01(4)$ & 0.004 \\
\hline $\begin{array}{l}\text { Source of germs responsible for } \\
\text { HCAI }\end{array}$ & $8(34.8)$ & $4(30.8)$ & $6(40)$ & $5(30.2)$ & $23(34.3)$ & $7.46(9)$ & 0.589 \\
\hline $\begin{array}{l}\text { Hand rubbing is more rapid for } \\
\text { hand cleansing than hand } \\
\text { washing }\end{array}$ & $21(91.3)$ & $12(92.3)$ & $10(66.7)$ & $16(100)$ & $59(88.1)$ & $1.184(3)$ & 0.027 \\
\hline $\begin{array}{l}\text { Minimal time for alcohol based } \\
\text { hand rub to be effective }\end{array}$ & $14(60.9)$ & $4(30.8)$ & $9(60)$ & $14(87.5)$ & $41(61.2)$ & $23.03(9)$ & 0.006 \\
\hline
\end{tabular}

Table 2.1: Hand hygiene's Knowledge of House Officers ( $n=67)$.

\begin{tabular}{|c|c|c|c|c|c|c|c|c|c|}
\hline Variables & Sub-domains & & 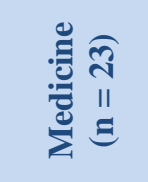 & 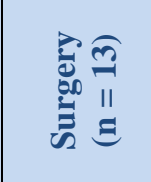 & 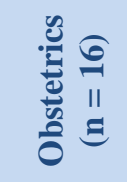 & 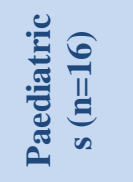 & 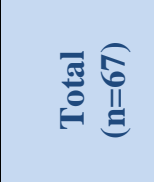 & 寻莺 & 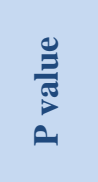 \\
\hline \multirow{2}{*}{$\begin{array}{l}\text { Actions } \\
\text { preventing } \\
\text { transmission to } \\
\text { patient }\end{array}$} & $\begin{array}{l}\text { 1. Before } \\
\text { touching a } \\
\text { patient }\end{array}$ & Yes & $22(99.7)$ & $12(92.3)$ & $12(80)$ & $16(100)$ & $62(92.5)$ & $2.09(3)$ & 0.551 \\
\hline & $\begin{array}{l}\text { 2. After body } \\
\text { fluid exposure }\end{array}$ & No & $1(4.3)$ & $1(4.7)$ & $0(0)$ & $0(0)$ & $2(3)$ & $2.19(3)$ & 0.553 \\
\hline
\end{tabular}




\begin{tabular}{|c|c|c|c|c|c|c|c|c|c|}
\hline & $\begin{array}{l}\text { 3. After exposure } \\
\text { to the immediate } \\
\text { surroundings of a } \\
\text { patient }\end{array}$ & Yes & $21(91.3)$ & $13(100)$ & $12(80)$ & $15(93.8)$ & $61(91)$ & $3.66(3)$ & 0.300 \\
\hline & $\begin{array}{l}\text { 4. Immediately } \\
\text { before a } \\
\text { clean/aseptic } \\
\text { Procedure }\end{array}$ & No & $2(8.7)$ & $1(7.7)$ & $0(0)$ & $0(0)$ & $3(4.5)$ & $2.72(3)$ & 0.436 \\
\hline $\begin{array}{l}\text { Actions } \\
\text { Preventing } \\
\text { transmission to } \\
\text { health workers }\end{array}$ & $\begin{array}{l}\text { 1.After touching } \\
\text { a patient }\end{array}$ & Yes & $23(100)$ & $12(92.3)$ & $15(100)$ & $16(100)$ & 66 (98.5) & $4.21(3)$ & 0.239 \\
\hline & $\begin{array}{l}\text { 2.Immediately } \\
\text { after a risk of } \\
\text { body fluid } \\
\text { exposure }\end{array}$ & Yes & $20(87)$ & $11(84.6)$ & $15(100)$ & $16(100)$ & $62(92.5)$ & $4.71(3)$ & 0.194 \\
\hline & $\begin{array}{l}\text { 3.Immediately } \\
\text { before a } \\
\text { clean/aseptic } \\
\text { procedure }\end{array}$ & No & $0(0)$ & $0(0)$ & $2(13.3)$ & $2(12.5)$ & $4(6)$ & $4.79(3)$ & 0.176 \\
\hline & $\begin{array}{l}\text { 4.After exposure } \\
\text { to the immediate } \\
\text { surroundings of a } \\
\text { patient }\end{array}$ & Yes & $21(91.3)$ & $12(92.3)$ & $15(100)$ & $14(87.5)$ & $62(92.5)$ & $4.95(3)$ & 0.604 \\
\hline \multirow{6}{*}{$\begin{array}{l}\text { Type of hand } \\
\text { hygiene required }\end{array}$} & $\begin{array}{l}\text { Before palpation } \\
\text { of the abdomen }\end{array}$ & $\begin{array}{l}\text { Rub } \\
\text { bing }\end{array}$ & $6(26.1)$ & $8(61.5)$ & $7(46.7)$ & $3(18.8)$ & $24(35.8)$ & $18.57(6)$ & 0.05 \\
\hline & $\begin{array}{l}\text { Before giving an } \\
\text { injection }\end{array}$ & $\begin{array}{l}\text { Rub } \\
\text { bing }\end{array}$ & $10(43.5)$ & $12(92.3)$ & $7(46.7)$ & $11(68.8)$ & $40(59.7)$ & $16.16(6)$ & 0.013 \\
\hline & $\begin{array}{l}\text { After emptying a } \\
\text { bedpan }\end{array}$ & $\begin{array}{l}\text { Rub } \\
\text { bing }\end{array}$ & $15(65.2)$ & $5(38.5)$ & $6(40)$ & $7(43.8)$ & $33(49.3)$ & $6.90(6)$ & 0.329 \\
\hline & $\begin{array}{l}\text { After removing } \\
\text { examination } \\
\text { gloves }\end{array}$ & $\begin{array}{l}\text { Rub } \\
\text { bing }\end{array}$ & $4(17.4)$ & $9(69.2)$ & $7(46.7)$ & $7(43.8)$ & $27(40.3)$ & $13.74(6)$ & 0.333 \\
\hline & $\begin{array}{l}\text { After preparing a } \\
\text { patient's bed }\end{array}$ & $\begin{array}{l}\text { Rub } \\
\text { bing }\end{array}$ & $9(39.1)$ & $7(53.8)$ & $9(60)$ & $3(18.8)$ & $28(41.8)$ & $10.78(6)$ & 0.095 \\
\hline & $\begin{array}{l}\text { After visible } \\
\text { exposure to } \\
\text { blood }\end{array}$ & $\begin{array}{l}\text { Was } \\
\text { hing }\end{array}$ & $12(52.2)$ & $7(53.8)$ & $9(60)$ & $11(68.8)$ & $39(58.2)$ & $3.38(6)$ & 0.759 \\
\hline \multirow{4}{*}{$\begin{array}{l}\text { Avoidance to } \\
\text { prevent skin } \\
\text { colonization }\end{array}$} & \begin{tabular}{|l} 
Wearing \\
jewellery
\end{tabular} & Yes & $17(73.9)$ & $11(84.6)$ & $12(80)$ & $10(62.5)$ & $50(74.6)$ & $2.16(3)$ & 0.539 \\
\hline & Skin damage & Yes & $22(95.7)$ & $12(92.3)$ & $15(100)$ & $15(93.8)$ & 64 (95.5) & $1.13(6)$ & 0.768 \\
\hline & $\begin{array}{l}\text { Artificial } \\
\text { fingernails }\end{array}$ & Yes & $23(100)$ & $10(76.9)$ & $11(73.3)$ & $15(93.8)$ & $59(88.1)$ & $8.23(3)$ & 0.041 \\
\hline & $\begin{array}{l}\text { Regular use of a } \\
\text { hand cream }\end{array}$ & No & $13(56.6)$ & $4(30.8)$ & $2(13.3)$ & $4(25)$ & $23(34.3)$ & $8.64(3)$ & 0.034 \\
\hline
\end{tabular}


Table 3: Hand hygiene's perception of House Officers $(n=67)$. (The figures in parenthesis are percentages).

\begin{tabular}{|l|l|l|l|l|l|l|l|l|}
\hline Variables & Response & $\begin{array}{c}\text { Medicine } \\
(\mathbf{n}=\mathbf{2 3})\end{array}$ & $\begin{array}{c}\text { Surgery } \\
(\mathbf{n}=13)\end{array}$ & $\begin{array}{c}\text { Obstetrics } \\
(\mathbf{n}=15)\end{array}$ & $\begin{array}{c}\text { Paediatrics } \\
(\mathbf{n}=\mathbf{1 6})\end{array}$ & $\begin{array}{c}\text { Total } \\
(\mathbf{n}=67)\end{array}$ & $\begin{array}{c}\text { Chi square } \\
(\mathbf{d f})\end{array}$ & $\begin{array}{c}\text { P- } \\
\text { value }\end{array}$ \\
\hline $\begin{array}{l}\text { Impact of HCAI on } \\
\text { patient's clinical } \\
\text { outcome }\end{array}$ & High & $15(65.2)$ & $10(76.9)$ & $9(60)$ & $12(75)$ & $46(68.7)$ & $7.93(9)$ & 0.541 \\
\hline $\begin{array}{l}\text { Effectiveness of hand } \\
\text { hygiene }\end{array}$ & High & $13(56.5)$ & $11(84.6)$ & $12(80)$ & $9(56.2)$ & $45(67.2)$ & $12.68(9)$ & 0.178 \\
\hline $\begin{array}{l}\text { Importance of hand } \\
\text { hygiene }\end{array}$ & $\begin{array}{l}\text { Low } \\
\text { priority }\end{array}$ & $6(26.1)$ & $9(69.2)$ & $7(46.7)$ & $3(18.8)$ & $25(37.3)$ & $18.45(9)$ & 0.030 \\
\hline $\begin{array}{l}\text { Support of senior } \\
\text { managers in } \\
\text { promotion of hygiene }\end{array}$ & $\begin{array}{l}\text { Very } \\
\text { effective }\end{array}$ & $15(65.2)$ & $3(23.1)$ & $8(53.3)$ & $9(56.2)$ & $35(52.2)$ & $15.06(6)$ & 0.020 \\
\hline $\begin{array}{l}\text { Effectiveness of hand } \\
\text { rubs availability }\end{array}$ & $\begin{array}{l}\text { Very } \\
\text { effective }\end{array}$ & $17(73.9)$ & $5(38.5)$ & $4(26.7)$ & $9(56.2)$ & $35(52.2)$ & $22.00(6)$ & 0.001 \\
\hline $\begin{array}{l}\text { Effectiveness of } \\
\text { displaying posters }\end{array}$ & Effective & $4(17.4)$ & $4(30.8)$ & $13(86.7)$ & $5(31.2)$ & $26(38.8)$ & $21.65(6)$ & 0.001 \\
\hline $\begin{array}{l}\text { Effectiveness of } \\
\text { education }\end{array}$ & $\begin{array}{l}\text { Very } \\
\text { effective }\end{array}$ & $14(60.9)$ & $5(38.5)$ & $3(20)$ & $4(25)$ & $26(38.8)$ & $12.21(6)$ & 0.57 \\
\hline $\begin{array}{l}\text { Effectiveness of clear } \\
\text { instructions }\end{array}$ & Effective & $10(43.5)$ & $5(38.5)$ & $12(80)$ & $8(50)$ & $35(52.2)$ & $7.76(6)$ & 0.256 \\
\hline $\begin{array}{l}\text { Effectiveness of } \\
\text { feedback on } \\
\text { performance }\end{array}$ & Effective & $11(47.8)$ & $6(46.2)$ & $13(86.7)$ & $7(43.8)$ & $37(55.2)$ & $8.63(6)$ & 0.196 \\
\hline $\begin{array}{l}\text { Importance of head of } \\
\text { department }\end{array}$ & High & $7(30.4)$ & $5(38.5)$ & $7(46.7)$ & $12(75)$ & $31(46.3)$ & $5.02(3)$ & 0.02 \\
\hline
\end{tabular}

\section{Discussion}

The present study did not document satisfactory level of knowledge regarding standard hand hygiene. Only $40 \%$ of house officers answered correctly when asked about the main route of transmission of potentially harmful germs between patients while $23 \%$ of house officers had correct knowledge about most frequent source of germs responsible for HCAI's. This finding is even lower than that reported in other studies done via a similar methodology in neighboring countries like Iran, Kuwait and India. ${ }^{11-13}$ This may be due to a lack of hand hygiene resources in our hospitals, and there may be insufficient knowledge about hand hygiene. An alternative explanation is that although guidelines are simple and easy to learn, translating them into practice in a working environment is a challenge. ${ }^{4}$ Our results are in contrast to other studies where authors found that $>72 \%$ of participants had correct knowledge about main route of transmission. ${ }^{8,15,16}$ In the present study, correct knowledge regarding alcohol free hand rub was better $(80 \%)$ among house officers. However, only $61 \%$ of the house officers had correctly answered about the minimum time needed for effective hand hygiene. However, our observations were similar to studies carried out by Khaled et al, Nair et al and Ariyaratne et al. ${ }^{8,6,17}$

Present study also documented the hand hygiene perception of house officers, where they were of the opinion that the health care facility should make alcohol based hand-rub always available at each point of care and awareness posters should be displayed at point of care as reminders. They were also of the opinion that the actions taken by leaders and managers regarding effective measures towards hand hygiene will create the difference in improving the hand hygiene practice. This is comparable to the observantions by Jang et al where participants considered high important role for management factors and believed 
that respectable communication patterns, team efforts, and the education of house officers about how to comply with hand hygiene guidelines, despite the high workload, are important factors. ${ }^{18}$

This study has certain limitations. This study was conducted in a single institute setup. It was a crosssectional survey conducted with a limited sample size. A questionnaire was used for assessment, and thus, likely to be affected by bias. Further multicentre studies and qualitative assessments are warranted to identify the potential gaps in hand hygiene among the fresh graduates or house officers.

\section{Conclusion}

The unsatisfactory hand hygiene knowledge responses indicate that the house officers require increased emphasis on hand hygiene education and improvement in their current primary training as well as undergraduate curricula.

\section{References}

1. Thakker VS, Jadhav PR. Knowledge of hand hygiene in undergraduate medical, dental, and nursing students: A cross sectional survey. J Family Med Prim Care, 2015; 4: 582-6.

2. Ergin A, Bostancı M, Önal O, Bozkurt AI, Ergin N. Evaluation of students' social hand washing knowledge, practices, and skills in a university setting. Cent Eur J Public Health, 2011; 19 (4): 222-7.

3. Longtin Y, Sax H, Allegranzi B, Schneider F, Pittet D. Videos in clinical medicine. Hand hygiene. N Engl $\mathrm{J}$ Med. 2011; 364: e24.

4. UNICEF. Global Handwashing Day 15 October: Planner's guide. 2008. [cited 2015 Dec 27]. Available from: http://www.unicef.org/lac/GHD_Planners_Guide.pdf..

5. World Health Organisation. WHO Guidelines on Hand Hygiene in Health Care: First Global Patient Safety Challenge Clean Care Is Safer Care. Geneva: World Health Organization Press; 2009. [cited 2015 Dec 27]. Available from: http://www.whqlibdoc.who. int/publications/2009/9789241597906_eng.pdf.

6. Nair SS, Hanumantappa R, Hiremath SG, Siraj MA, Raghunath P. Knowledge, attitude, and practice of hand hygiene among medical and nursing students at a tertiary health care centre in Raichur, India. ISRN Prev Med. 2014; 2014: 608927.

7. van de Mortel TF, Apostolopoulou E, Petrikkos G. A comparison of the hand hygiene knowledge, beliefs, and practices of Greek nursing and medical students. Am J Infect Control, 2010; 38: 75-7.

8. Ariyaratne M, Gunasekara T, Weerasekara MM, Kottahachchi J, Kudavidanage BP, Fernando SS. Knowledge, attitudes and practices of hand hygiene among final year medical and nursing students at the University of Sri Jayewardenepura. Sri Lankan J Infect Dis. 2013; 3: 15-25.

9. World Health Organization [Internet]. Geneva: World Health Organization; 2016 [cited 2016 May 05]. Available from:

www.who.int/gpsc/5may/Hand_Hygiene_Knowledge_ Questionnaire.doc

10. www.who.int/gpsc/.../Perception_Survey_for_Health_ care_Workers.doc

11. Nabavi M, Alavi - Moghaddam M, Gachkar L, Moeinian M. Knowledge, attitudes, and practices study on hand hygiene among imam hossein hospital's residents in 2013. Iran Red Crescent Med J. 2015; 17 (10): e19606.

12. Al-Wazzan B, Salmeen Y, Al-Amiri E, Abul A, Bouhaimed M, Al-Taiar A. Hand hygiene practices among nursing staff in public secondary care hospitals in Kuwait: self - report and direct observation. Med Princ Pract. 2011; 20 (4): 326-31.

13. Sharma S, Sharma S, Puri S, Whig J. Hand hygiene compliance in the intensive care units of a tertiary care hospital. Indian J Community Med. 2011; 36 (3): 217 21.

14. Erasmus V, Brouwer W, van Beeck EF, Oenema A, Daha TJ, Richardus JH. A qualitative exploration of reasons for poor hand hygiene among hospital workers: lack of positive role models and of convincing evidence that hand hygiene prevents cross - infection. Infect Control Hosp Epidemiol. 2009; 30 (5): 415-9.

15. Tenna A, Stenehjem EA, Margoles L, Kacha E, Blumberg HM, Kempker RR. Infection control knowledge, attitudes, and practices among healthcare workers in Addis Ababa, Ethiopia. Infect Control Hosp Epidemiol. 2013; 34 (12): 1289-96.

16. Maheshwari V, kaore NCM, Ramnani VK, Gupta SK, Borle A, Kaushal R. A study to assess knowledge and attitude regarding hand hygiene amongst residents and nursing staff in a tertiary health care setting of Bhopal city. J Clin Diagn Res. 2014; 8 (8): DC04-DC07.

17. Khaled M, Elaziz A, Bakr IM. Assessment of knowledge, attitude and practice of hand washing among health care workers in Ain Shams University hospitals in Cairo. The Egyptian Journal of Community Medicine, 2008; 26 (2): 1-12.

18. Jang JH, Wu S, Kirzner D, Moore C, Youssef G, Tong A, et al. Focus group study of hand hygiene practice among healthcare workers in a teaching hospital in Toronto, Canada. Infect Control Hosp Epidemiol. 2010; 31 (2): 144-50. 